\title{
Characterization of a volcanic ash episode in southern Finland caused by the Grimsvötn eruption in Iceland in May 2011
}

\author{
V.-M. Kerminen ${ }^{1,2}$, J. V. Niemi ${ }^{3,4}$, H. Timonen ${ }^{1}$, M. Aurela ${ }^{1}$, A. Frey ${ }^{1}$, S. Carbone ${ }^{1}$, S. Saarikoski ${ }^{1}$, K. Teinilä ${ }^{1}$, \\ J. Hakkarainen ${ }^{1}$, J. Tamminen ${ }^{1}$, J. Vira ${ }^{1}$, M. Prank ${ }^{1}$, M. Sofiev ${ }^{1}$, and R. Hillamo ${ }^{1}$ \\ ${ }^{1}$ Finnish Meteorological Institute, Research and Development, P.O. Box 505, 00101, Helsinki, Finland \\ ${ }^{2}$ Department of Physics, University of Helsinki, P.O. Box 64, 00014, Helsinki, Finland \\ ${ }^{3}$ Helsinki Region Environmental Services Authority HSY, P.O. Box 100, 00066, Helsinki, Finland \\ ${ }^{4}$ Department of Environmental Sciences, University of Helsinki, P.O. Box 65, 00014, Helsinki, Finland
}

Received: 30 August 2011 - Published in Atmos. Chem. Phys. Discuss.: 5 September 2011

Revised: 4 November 2011 - Accepted: 16 November 2011 - Published: 7 December 2011

\begin{abstract}
The volcanic eruption of Grimsvötn in Iceland in May 2011 affected surface-layer air quality at several locations in Northern Europe. In Helsinki, Finland, the main pollution episode lasted for more than $8 \mathrm{~h}$ around the noon of 25 May. We characterized this episode by relying on detailed physical, chemical and optical aerosol measurements. The analysis was aided by air mass trajectory calculations, satellite measurements, and dispersion model simulations. During the episode, volcanic ash particles were present at sizes from less than $0.5 \mu \mathrm{m}$ up to sizes $>10 \mu \mathrm{m}$. The mass mean diameter of ash particles was a few $\mu \mathrm{m}$ in the Helsinki area, and the ash enhanced $\mathrm{PM}_{10}$ mass concentrations up to several tens of $\mu \mathrm{g} \mathrm{m}^{-3}$. Individual particle analysis showed that some ash particles appeared almost non-reacted during the atmospheric transportation, while most of them were mixed with sea salt or other type of particulate matter. Also sulfate of volcanic origin appeared to have been transported to our measurement site, but its contribution to the aerosol mass was minor due the separation of ash-particle and sulfur dioxide plumes shortly after the eruption. The volcanic material had very little effect on $\mathrm{PM}_{1}$ mass concentrations or sub-micron particle number size distributions in the Helsinki area. The aerosol scattering coefficient was increased and visibility was slightly decreased during the episode, but in general changes in aerosol optical properties due to volcanic aerosols seem to be difficult to be distinguished from those induced by other pollutants present in a continental boundary layer. The case investigated here demonstrates clearly the
\end{abstract}

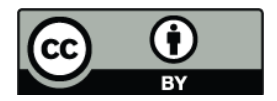

Correspondence to: V.-M. Kerminen (veli-matti.kerminen@helsinki.fi) power of combining surface aerosol measurements, dispersion model simulations and satellite measurements in analyzing surface air pollution episodes caused by volcanic eruptions. None of these three approaches alone would be sufficient to forecast, or even to unambiguously identify, such episodes.

\section{Introduction}

Volcanic eruptions perturb aerosol and trace gas budgets in the troposphere and stratosphere, having thereby a potential to influence the global climate, air traffic, soils and vegetation, as well as animals and humans. The effects of volcanic eruptions depend crucially on the magnitude, type and height of emissions. Climatic effects by volcanoes remain minor unless a large amount of sulfur dioxide is being injected to the stratosphere (Robock et al., 2000; Graf et al., 2007; Schneider et al., 2009). Volcanic ash may cause serious damage to air craft (e.g. Guffanti et al., 2009; Gislason et al., 2011), and even relatively moderate concentrations of ash particles in the middle and upper troposphere may force air traffic authorities to change flight routes or to cancel flights (Prata, 2009; Schumann et al., 2011). Both gaseous and particulate emissions by volcanoes may have adverse effects on the environment and human health (e.g. Thordarson and Self, 2003), but this is possible only when the emissions enter the boundary layer by either direct air mass transport or sedimentation.

Surface air pollution and associated effects caused by volcanic eruptions have been investigated to a very limited

Published by Copernicus Publications on behalf of the European Geosciences Union. 
extent. One of the most widely-documented cases in this respect has been the Laki eruption that took place in Iceland during 1783-1784, causing serious environmental and health problems over large areas in Europe and even farther away (Thordarson and Self, 2003). The eruption of Eyjafjallajökull in Iceland during April-May, 2010, initiated a big number of research activities to characterize the physical, chemical and optical properties of airborne volcanic material associated with this eruption. Over the continental Europe, the signal from the Eyjafjallajökull eruption was strongest above the boundary layer (e.g. Ansmann et al., 2010; Gasteiger et al., 2011; Schäfer et al., 2011; Schumann et al., 2011), but it could also be detected in the surface air and ground deposits (e.g. Colette et al., 2010; Flentje et al., 2010; Lettino et al., 2011; Revuelta et al., 2011; Rossini et al., 2011).

The main challenge in measuring volcanic material in the surface air is that this material is always mixed with other pollutants present in the boundary layer. In this paper, we will document a prominent surface air pollution episode observed in Helsinki, Finland, caused by long-range transported volcanic material from the Grimsvötn eruption that took place at the end of May 2011, in Iceland. The pollution episode investigated here was observed on 25 May 2011, and it was characterized in detail by a number of different measurement devices. In this paper, we aim to address the following two questions: (1) what were the physical and chemical properties of volcanic aerosol particles after being entrained into the boundary layer air, and (2) how well these particles could be separated from other natural and anthropogenic aerosol particles present in measured air masses? In addition to providing new information about long-range transported volcanic aerosol particles, we will briefly discuss the compatibility of our observations with satellite measurements and dispersion model simulations.

\section{Materials and methods}

\subsection{Aerosol measurements}

Excluding the particle number size distribution and $\mathrm{PM}_{2.5} / \mathrm{PM}_{10}$ data, the aerosol measurements discussed in this paper were conducted at the urban background station SMEAR III (Station for Measuring Ecosystem-Atmosphere Relationships; $60^{\circ} 20^{\prime} \mathrm{N}, 24^{\circ} 97^{\prime} \mathrm{E}, 26 \mathrm{~m}$ above sea level) in Helsinki, Finland. The SMEAR III station is located in the heart of the Helsinki Metropolitan Area about $5 \mathrm{~km}$ northeast from the Helsinki city center. The station is surrounded by university campus buildings, other buildings and small forested areas. The closest major road is located behind a few trees at the distance $<200 \mathrm{~m}$ from the station (Saarikoski et al., 2008; Järvi et al., 2009).

The $\mathrm{PM}_{1}$ mass concentrations were continuously measured using a Tapered Element Oscillating Microbalance
(TEOM ${ }^{\complement}$ 1400a, Rupprecht \& Patashnick; Allen et al., 1997). A cyclone (sharp cut cyclone SCC 1.829, BGI Inc. US) was used prior to the TEOM to cut off large particles (aerodynamic diameter $>1 \mu \mathrm{m}$ ). The uncertainty of the TEOM results was estimated to be $10 \%$.

An aerosol chemical speciation monitor (ACSM) was used to measure the mass and chemical composition (sulphate, nitrate, ammonium, chloride and organics) of non-refractory submicron particulate matter. The time resolution of the measurements was one hour. The ACSM is described in detail by $\mathrm{Ng}$ et al. (2011). Shortly, the sample flow rate into the instrument $\left(\sim 85 \mathrm{~cm}^{3} \mathrm{~min}^{-1}\right)$ is fixed by a $100-\mu \mathrm{m}$-diameter critical aperture. An aerodynamic lens is used to focus the particle beam. The measured particle size is controlled by an aerodynamic lens that has transmission $>50 \%$ over the range from 75 to $650 \mathrm{~nm}$ (Liu et al. 2007). Three vacuum pumps (Pfeiffer, two HP300 and one HP80) and one backup diaphragm pump (Vacuubrand, MD1) are used to generate vacuum into the instrument. Focused particle beam impacts the vaporizer $\left(600^{\circ} \mathrm{C}\right)$ and formed vapor is ionized by electron impaction. Compounds that are vaporized and ionized are detected by a residual gas analyzer (RGA) type quadrupole mass analyzer. The ACSM measures background automatically by alternating sample flow through a filter line and the normal sample line. The particle signal is calculated by subtracting the background results (filter mode measurements) from the sample results. The detection chamber contains a naphthalene source, which provides an internal standard for calibrating the mass to charge ratios of the measured ions.

Aerosol scattering and absorption coefficient were measured using a three-wavelength nephelometer (TSI Model 3563) and aethalometer (Magee Scientific, AE20), respectively. For both these instruments, air was collected both through a $\mathrm{PM}_{1}$ inlet removing super-micron particles and without inlet and size discrimination during the epidode.

After realizing that volcanic aerosol had probably entered the Helsinki area on 25 May, we initiated impactor sampling for chemical analysis by ion chromatography (IC) and individual particle analysis by transmission electron microscopy (TEM) coupled with energy-dispersive X-ray (EDX) microanalyses. Between 11:37 and 15:05 local summer time $(=\mathrm{UTC}+3 \mathrm{~h})$ on 25 May, five stages (the stages 1, 2, 3, 4 and 7 with cut-off diameters of 0.2, 0.5, 1.0, 1.8 and $11 \mu \mathrm{m}$, respectively) of a single orifice Battelle type impactor (model I-1, PIXE International Corporation, Florida, USA, modified from the original Battelle design, Mitchell and Pilcher, 1959) were used to collect samples for the TEM/EDX analysis (description in the next section). The sample collection with a volume flow rate of 1 liters per minute took place onto 3-mm TEM grids (Cu with carbon-coated Formvar films, 400-mesh, Carbon Type-B, Ted Pella Inc., Redding, CA, USA). Between 15:15 and 17:00 on the same day, the four highest stages (cut-off diameters of 1.0, 1.8, 3.2 and $5.6 \mu \mathrm{m}$ ) of a Micro-Orifice Uniform Deposit Impactor (MOUDI, Marple et al., 1991) were used to collect 
supermicron aerosol particles for the IC analysis (description in the next section). The MOUDI samples were collected with a volume flow rate of 30 liter per minute onto 47-mm polycarbonate filters with $0.4 \mu \mathrm{m}$ pore size (Isopore membrane filters, Millipore). An inlet with a cut-off diameter of $10 \mu \mathrm{m}$ (Liu and Pui, 1981) was used on the top of the sampling line at about five meters above the ground level.

Particle number size distributions were measured as a part of a technical test conducted at the ventilation room of an elementary school (Ressu comprehensive school, Lapinlahdenkatu 10, Helsinki) in the Helsinki city centrum. Automatic valves were used to alternate the measurements between ambient air prior filter and ventilated air after filter. Only data from ambient measurements are used in this article. Particle number size distributions were measured in the size range of $9-414 \mathrm{~nm}$ with a scanning mobility particle sizer (SMPS, TSI Model 3080/3081) and in the size range of $0.5-20 \mu \mathrm{m}$ with an aerosol particle sizer (APS, TSI Model 3321). In case of the APS, losses of coarse particles inside the ventilation channels and valves were plausible. By comparing the APS-derived mass concentrations with the $\mathrm{PM}_{2.5}$ and $\mathrm{PM}_{10}$ mass measurements elsewhere in the Helsinki area, these losses were estimated to be up to 50$70 \%$, mostly for particles $>5 \mu \mathrm{m}$ in aerodynamic diameter.

\subsection{Analysis of collected aerosol samples}

From the MOUDI filter samples, the major inorganic $\left(\mathrm{Na}^{+}\right.$, $\mathrm{NH}_{4}^{+}, \mathrm{K}^{+}, \mathrm{Mg}^{2+}, \mathrm{Ca}^{2+}, \mathrm{Cl}^{-}, \mathrm{NO}_{3}^{-}, \mathrm{SO}_{4}^{2-}$ ) water-soluble ions were analyzed by using an ion chromatograph (Dionex ICS-2000). The AG17/CG12A guard column, AS17/CS12A analytical column, $500 \mu \mathrm{l}$, ASRS/CSRS ultra II suppressor and $\mathrm{KOH} / \mathrm{MSA}$ eluent were used to analyze anions/cations. The uncertainty of the IC analyses of the filters was about $5-10 \%$ for all of the analyzed ions.

The morphology and elemental composition of individual aerosol particles were investigated using a Tecnai 12 transmission electron microscope (TEM) equipped with an EDAX energy dispersive X-ray (EDX) microanalyser. The TEM was operated on an accelerating voltage of $120 \mathrm{kV}$ and with a low beam current to minimize beam damage. Counting time for X-ray spectra was 20 live seconds. The minimum size of particles analyzed was $0.2 \mu \mathrm{m}$ (geometric diameter). The elements analysed were from $\mathrm{C}$ to $\mathrm{Pb}$, excluding $\mathrm{N}$. The $\mathrm{X}$ ray counts from carbon-Formvar coating (thickness listed as $60 \mathrm{~nm}$; contains abundant $\mathrm{C}$, some $\mathrm{O}$ and very minor $\mathrm{Si}$ ) of TEM grids were estimated by analyzing blank areas between particles. The X-ray count ratios of elements for each particle were normalized to $100 \%$. Although the elemental results were semi-quantitative, the accuracy is sufficient to identify different particle types and to compare the differences in elemental ratios of the same particle type in different samples (see Niemi et al., 2006, and references therein). The strong vacuum $\left(10^{-7}\right.$ torr) and beam exposure causes evaporation of semi-volatile compounds from particles, and for that rea- son water, ammonium nitrate and organic compounds with high vapour pressures were lost, as is typical in electron microscopy.

\subsection{Satellite measurements}

In order to study the ash plume arrival to Finland we have used the observations retrieved from the measurements made by the Dutch-Finnish Ozone Monitoring Instrument (OMI) on-board NASA's polar orbiting EOS-Aura satellite. OMI measures scattered solar light in UV-VIS wavelengths and several trace gases (including $\mathrm{O}_{3}, \mathrm{NO}_{2}, \mathrm{SO}_{2}, \mathrm{HCHO}$ and $\mathrm{BrO}$ ), aerosols and surface UV-radiation can be retrieved from the measurements (Levelt et al., 2006). The ground pixel size is at best $13 \times 24 \mathrm{~km}$ in nadir and larger at swath ends. Since 2009 the so called OMI row anomaly has degraded the global coverage which is now obtained in two days instead of daily coverage in the beginning of the mission in 2004. Naturally, this has also affected OMI's capability to monitor volcanic ash and $\mathrm{SO}_{2}$.

There are two aerosol products from OMI: OMAEROUV and OMAERO. The first one continues the traditional Total Ozone Mapping Spectrometer (TOMS) aerosol products and the latter one is a multi-wavelength product taking advantage of the wider spectral region of OMI (Torres et al., 2007). The ash and $\mathrm{SO}_{2}$ emitted from volcanoes have been successfully seen in $\mathrm{OMI} \mathrm{SO}_{2}$ and UV Aerosol Index products. The OMI $\mathrm{SO}_{2}$ retrieval technique is based on band residual difference algorithm defined in Krotkov et al. (2006). In this work we have used the middle troposphere (TRM) $\mathrm{SO}_{2}$ product that assumes the center of mass altitude to be at $7.5 \mathrm{~km}$.

In addition to $\mathrm{SO}_{2}$, we have used the OMI Absorbing Aerosol Index (AAI) which is a qualitative measure that indicates the presence of UV-absorbing aerosols, such as smoke, dust and volcanic ash, in the atmosphere. Originally, it was developed empirically from TOMS observations (Torres et al., 1998). Since the algorithm is simple and robust and does not take assumptions on aerosol microphysics and compositions, AAI has been used in numerous studies of transported aerosols (see, e.g. Dirksen et al., 2009). The UV aerosol index is essentially a measure of scattering compared to fully molecular atmosphere with only Rayleigh scattering. The AAI is the positive part of the UVAI values, while negative UVAI values indicate non-absorbing aerosols and clouds. The UVAI is close to zero when the atmosphere is free from aerosols. The advantage of the AAI is that it is useful indicator of aerosols over large variety of land surfaces as well as above sea (with the exception of snow covered regions) (Torres et al., 2007). Compared to the OMI Aerosol optical depth (AOD) product that is sensitive to clouds, the AAI, while not a geophysical quantity, is also useful when the aerosols are present above clouds. OMI scientific data are publicly available from NASA's Mirador Earth Science Data Search Tool and near real time (NRT) data are available from NASA's LANCE and KNMI's TEMIS services. OMI 
direct broadcast data over Europe, Iceland and Greenland are available from OMI Very fast delivery site.

\subsection{Other materials and methods}

The total mass concentrations of aerosol particle smaller than $2.5 \mu \mathrm{m}\left(\mathrm{PM}_{2.5}\right)$ and $10 \mu \mathrm{m}\left(\mathrm{PM}_{10}\right)$ in diameter are continuously measured at several sites in the Helsinki Metropolitan Area by the Helsinki Region Environmental Services Authority (HSY). The results from Kallio urban background station were selected for this work since Kallio station is located close $(<2 \mathrm{~km})$ to SMEAR III station and the same PM monitor type $\left(\mathrm{TEOM}^{\complement}{ }^{\circledR}\right.$ 1400a) is used at both stations. We also utilized PM results from other monitoring sites in Finland (Finnish national air quality portal; www.ilmanlaatu.fi), Norway (Norwegian national air quality portal; http://www. luftkvalitet.info) and Sweden (Stockholm - Uppsala County Air Quality Management Association; www.slb.nu) to obtain general overview on the spatial distribution and timing of the episode.

Basic meteorological quantities, including visibility, and selected trace gas concentrations are continuously measured at the SMEAR III station (e.g. Järvi et al., 2009). Air mass back trajectories for the time period considered here were determined using the NOAA hysplit model (Draxler and Rolph, 2011; Rolph, 2011). Trajectories were calculated for $72 \mathrm{~h}$ backward in time at three arrival heights $(0,500$ and $3000 \mathrm{~m}$ a.s.l) and arrival time of 00:00 UTC each day.

Dispersion of volcanic emissions was simulated with the System for Integrated modeLling of Atmospheric coMposition SILAM (Sofiev et al., 2006, 2008). The dynamic core of the model is based on the transport scheme of Galperin $(1999,2000)$ combined with the extended resistance analogy of Sofiev (2002) for vertical diffusion. The removal processes are described via dry and wet deposition. Dry deposition follows Slinn and Slinn (1980). The SILAM wet deposition parameterization (Sofiev et al., 2006; Horn et al., 1987; Smith and Clark, 1989; Jylhä, 1991) is based on direct observations for moderately hydrophobic aerosols. For the current study, the meteorological information was taken from the ECMWF meteorological model (http://www.ecmwf.int). Diagnosing the features of the boundary layer and the free troposphere followed Sofiev et al. (2010). The resolution of the simulations was $0.25^{\circ}$ with 19 vertical layers up to about $20 \mathrm{~km}$ above the surface. The emission source was defined by the plume top altitude as reported by the London Volcanic Ash Advisory Centre based on the observations of the Icelandic Meteorological Office. The mass flux was estimated from the eruption height using the relation of Mastin et al. (2009). The particle size spectrum was represented as a single bin centered at the diameter of around $3 \mu \mathrm{m}$. This fraction was assumed to comprise $1 \%$ of the eruption total mass flux.

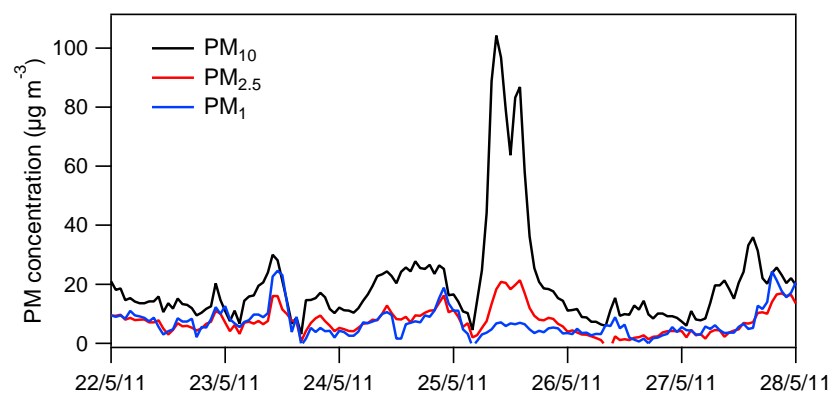

Fig. 1. $P M_{1}$ mass concentration measured at the SMEAR III station, together with $\mathrm{PM}_{2.5}$ and $\mathrm{PM}_{10}$ mass concentrations measured at another site (Kallio) in Helsinki between 22 and 28 May 2011.

\section{Results and discussion}

\subsection{General overview of the episode}

The pollution episode caused by the volcanic eruption was observed around the local noon on 25 May 2011 in the Helsinki area (Fig. 1). The highest $\mathrm{PM}_{10}$ mass concentrations $\left(>100 \mu \mathrm{g} \mathrm{m}^{-3}\right)$ were observed between about 09:00 and 10:00, after which there was a small dip in concentrations followed by a second maximum a couple of hours after the noon. Altogether, $\mathrm{PM}_{10}$ mass concentrations remained above $50 \mu \mathrm{g} \mathrm{m}^{-3}$ for more than $8 \mathrm{~h}$ in Helsinki. The great majority of the elevated particle mass concentrations could be explained by coarse particles (particle aerodynamic diameter between 2.5 and $10 \mu \mathrm{m}$ ), since the $\mathrm{PM}_{2.5}$ mass concentrations remained mainly below $20 \mu \mathrm{g} \mathrm{m}^{-3}$ and $\mathrm{PM}_{1}$ mass concentrations did not show any noticeable increases during the episode.

In order to put our observations into a broader context, we could note that annual-average $\mathrm{PM}_{10}$ mass concentrations are about $20 \mu \mathrm{g} \mathrm{m}^{-3}$ in the Helsinki area (Anttila and Salmi, 2006). The vast majority of short-term $\mathrm{PM}_{10}$ mass concentration peaks in Helsinki, like in several other northern cities, can be ascribed to traffic-induced dust formation because of the use of studded tyres and gravelling as antiskid treatments (Anttila and Tuovinen, 2010; Kupiainen and Pirjola, 2011). Road dust episodes are most frequent during the snowmelt period in spring, and similar to the episode considered here, they are seen most clearly in the coarse-particles size fraction. Air pollution episodes characterized by elevated $\mathrm{PM}_{2.5}$ mass concentrations are also observed in the Helsinki area every year. Such episodes are usually caused by long-range transported anthropogenic pollution or wildfire smokes from Eastern Europe and sometimes also by local wood burning activities or traffic exhaust (e.g. Vallius et al., 2003; Sillanpää et al., 2005; Saarikoski et al., 2008; Niemi et al., 2009). The long-range transport episodes of coarse particles are very rare in Finland (Tervahattu et al., 2004).

According to local wind measurements and air mass back trajectory calculations, westerly air masses prevailed 


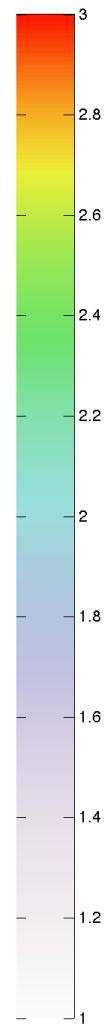

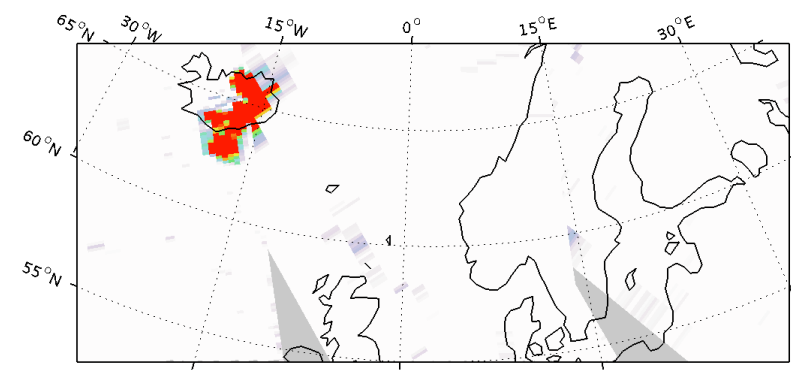

OMI AAl, 22.5.201

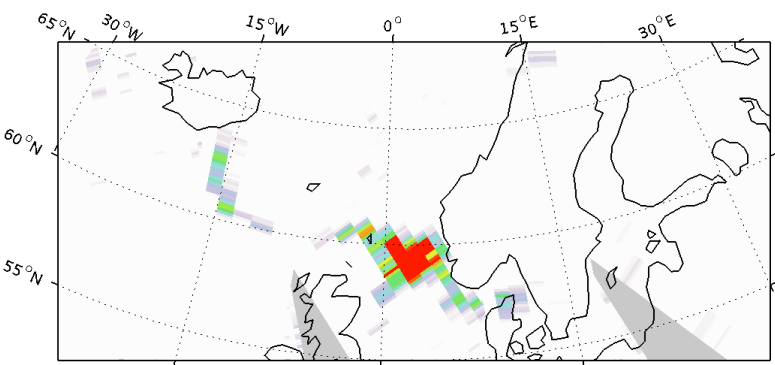

OMI AAI, 24.5.2011

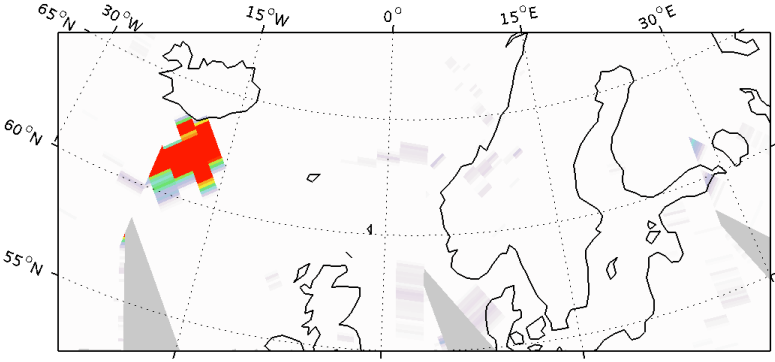

OMI AAI, 23.5.201

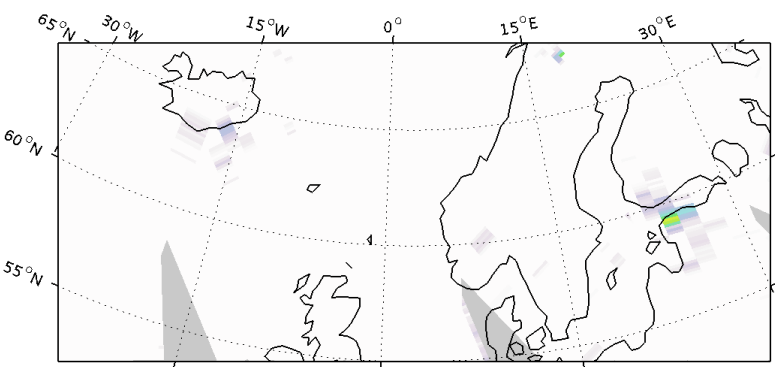

OMI AAI, 25.5.2011

Fig. 2. The AAI index measured by OMI during the afternoon on 22, 23, 24 and 25 May 2011.

between 22 and 28 May 2011. During the episode on 25 May, measured air masses originated from Northern Atlantic and typically traversed over the very southern parts Norway and over Sweden before entering Helsinki across the Baltic Sea. The average wind speed was relatively high between about 7 and $8 \mathrm{~m} \mathrm{~s}^{-1}$ during the episode, and the average temperature was in the range of $10-12{ }^{\circ} \mathrm{C}$ at the SMEAR III site in Helsinki.

The eruption of Grimsvötn started on 21 May, was at its strongest on 22 May, and then rapidly weakened during the next few days. Figure 2 shows the OMI AAI index during four days prior to the observed air pollution episode at the times of the satellite overpass. Indicative of ash emitted by Grimsvötn, we may see very large values of the AAI index over Iceland on 22 May and similarly high values South of Iceland in the following day. On 24 May the main part of the volcanic ash cloud approached Southern Norway. On 25 May this cloud was substantially diluted and the largest values of AAI could be observed over the Baltic Sea and Estonia, as well as over the southern parts of Finland. During the air pollution episode, OMI overpassed southern Finland twice (Fig. 3). The AAI indices measured during these two overpasses give strong support for the presence of a volcanic cloud over the Helsinki area during most of the episode, even though the thickest part of the cloud was probably located somewhat south of our measurement site.
It is interesting to note that high $\mathrm{PM}_{10}$ mass concentrations were measured at several sites in Southern Norway on 24 May. In Stockholm, Sweden, PM $_{10}$ concentrations started to increase during the late evening of 24 May and the episode lasted until the morning of 25 May. Besides the Helsinki area, the $\mathrm{PM}_{10}$ episode could be detected in several other locations of the very southern parts of Finland during 25 May. The $\mathrm{PM}_{10}$ and satellite measurements along with back trajectory calculations indicate strongly that the episode observed in Helsinki on 25 May was due to volcanic material ejected by Grimsvötn two to three days earlier, and that the same material affected also parts of Norway and Sweden.

Compared with the AAI index, the $\mathrm{SO}_{2}$ concentration retrieved by OMI showed a very different dispersion pattern. The main $\mathrm{SO}_{2}$ plume was located over Iceland on 22 May, after which it travelled over Greenland on 23 May and was then split into at least two separate plumes. On 24 May the largest $\mathrm{SO}_{2}$ concentrations were observed as about 300$\mathrm{km}$-wide belt that grossed Greenland and reached Northern America, and as a narrow stripe that went over the Arctic Ocean, Spitsbergen and Northern Siberia. On 25 May largest $\mathrm{SO}_{2}$ concentrations were observed to the west of Greenland, while some remains of the plume could be detected over different parts of Northern Atlantic and Arctic Ocean. The separation of volcanic ash and $\mathrm{SO}_{2}$ shortly after the eruption has been observed several times before (e.g. Schneider et al., 

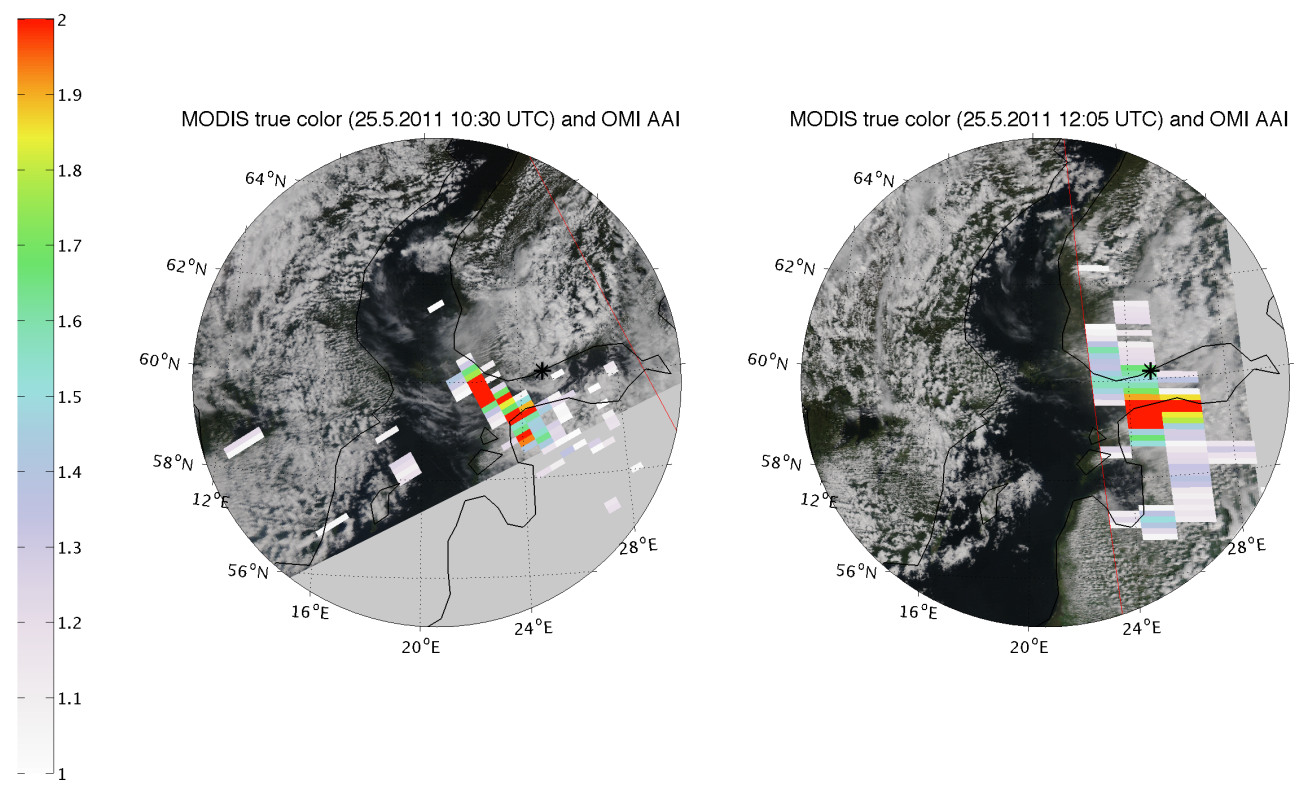

Fig. 3. The OMI AAI values $>1$ during the two OMI overpasses that took place on 25 May, together with MODIS/Aqua true color images. The MODIS granules are acquired at 10:30 and 12:05 UTC, and the OMI overpassed the same location $\sim 7$ min later.

1999; Prata and Kerkmann, 2007). Such a separation might be caused by potential differences in the timing and ejection heights of $\mathrm{SO}_{2}$ and ash particles emissions, or by the sedimentation of ash particles from the dispersing plume. The main practical consequence of this phenomenon is the presence of substantially less sulfate and fewer submicron particles than there would have been if $\mathrm{SO}_{2}$ and ash particles had been transported together.

Yet another way of investigating the transport of volcanic ash to our measurement site is to simulate it using a dispersion model. The simulated total aerosol column (Fig. 4) shows the volcanic plume reaching the northern Europe in 24 May with the highest column loadings dispersed over the North Sea and later, Southern Scandinavia and Baltic Sea. The simulated plume reaches Southern Finland during the 25 May. With the currently available input information, the model could not resolve the observed differences in the dispersion patterns of $\mathrm{SO}_{2}$ and ash, and the modeled aerosol column therefore has features of both observed $\mathrm{AAI}$ and $\mathrm{SO}_{2}$ column.

\subsection{Aerosol size distribution, chemical composition and optical properties}

The $\mathrm{PM}_{1}, \mathrm{PM}_{2.5}$ and $\mathrm{PM}_{10}$ measurements discussed in Sect. 3.1 indicate that the pollution episode observed on 25 May in the Helsinki area was mainly due to increased concentrations of super-micron (diameter $>1 \mu \mathrm{m}$ ) particles. Our number size distribution measurements give strong support for this view. The mass concentrations of super-micron particles derived from APS number size distributions increased several-fold during the episode with a peak diameter between about 3 and $4 \mu \mathrm{m}$ (Fig. 5). The real mass mean diameter of super-micron particles could have been somewhat bigger than this because of losses of $>5 \mu \mathrm{m}$ particles in our measurement system. Compared with other periods between 22 and 28 May, sub-micron particle number size distributions by the SMPS measurements did not show any specific features (data not shown). This is contrary to the Eyjafjällajökul eruption in April 2010, the plumes of which contained large numbers of sub-micron particles, presumably as a result of newparticle formation associated with the emitted $\mathrm{SO}_{2}$ (Flentje et al., 2010; Petäjä et al., 2011; Schäfer et al., 2011; Schumann et al., 2011). In our case, it is likely that the effective separation of $\mathrm{SO}_{2}$ from the ash particle plume transported to our measurement was the main cause of the lack of additional sub-micron particles.

Mass concentration of major inorganic ions in the four super-micron size fractions measured using the MOUDI impactor during the late part of the episode are shown in Fig. 6. The total concentration of inorganic ions in the sample was about $9 \mu \mathrm{g} \mathrm{m}^{-3}$. Sodium and chloride indicative of sea-salt particles explained most of this mass, and the next abundant ion was nitrate (about $1.5 \mu \mathrm{g} \mathrm{m}^{-3}$ ) followed by ammonium $\left(1.0 \mu \mathrm{g} \mathrm{m}^{-3}\right)$ and non-sea-salt sulfate $\left(0.6 \mu \mathrm{g} \mathrm{m}^{-3}\right)$. The estimated sea-salt mass concentrations exceeded the average sea-salt mass concentration at the Helsinki area during the spring/summer period by more than a factor 20 (see Kerminen et al., 2000). The probable reason for such a high amount of sea salt in our sample was the dominance of marine air masses combined with relatively strong wind speeds. Altogether, the analyzed ions explained less than $20 \%$ of the 

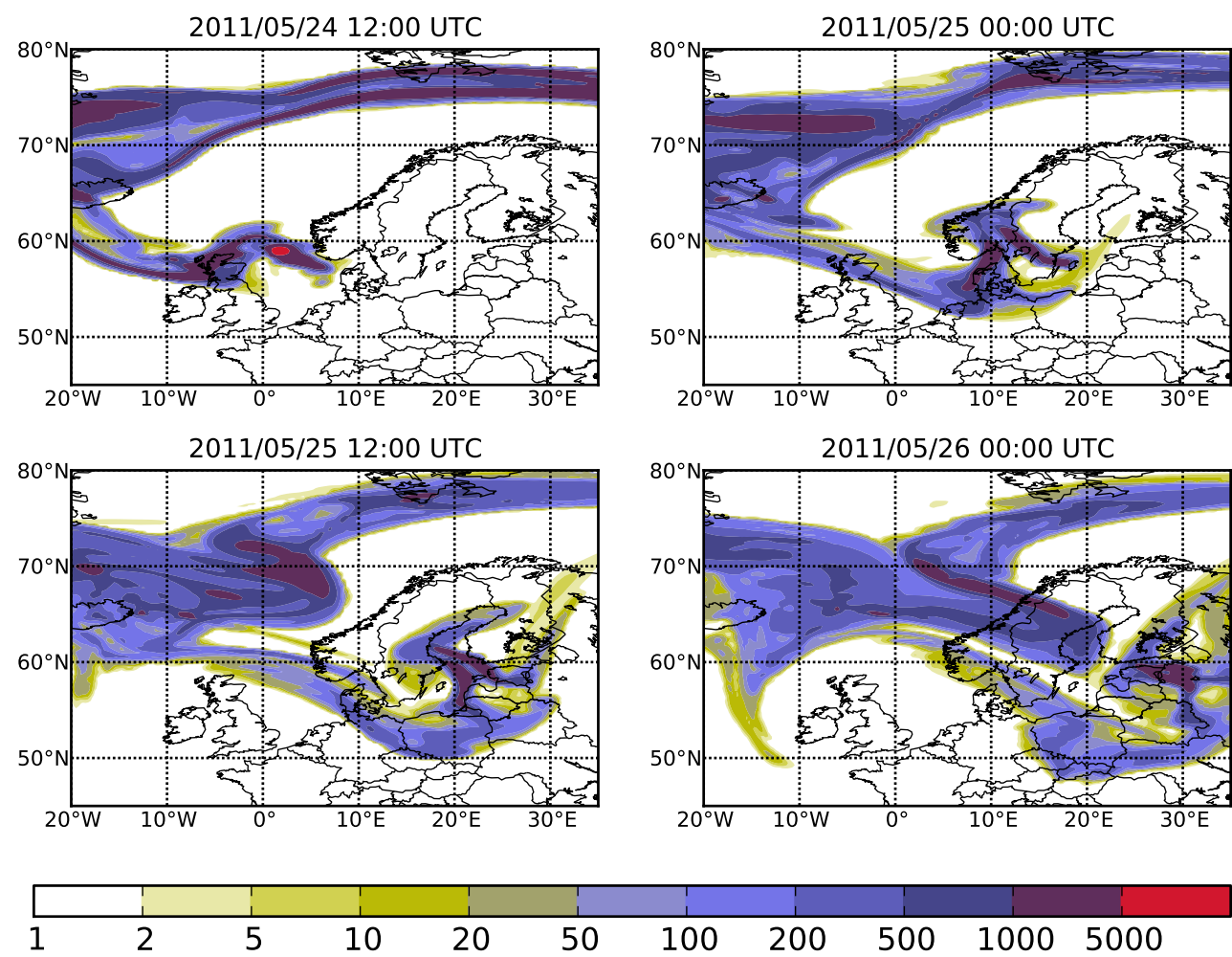

Fig. 4. The SILAM dispersion model results for the column-integrated volcanic ash concentration $\left(\mathrm{mg} \mathrm{m}^{-2}\right)$ during $24-25 \mathrm{May} 2011$.

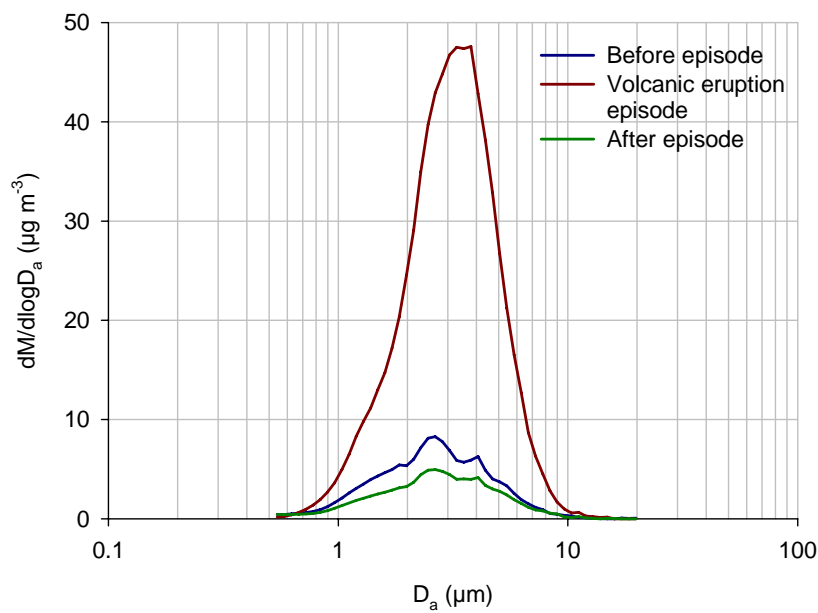

Fig. 5. APS-derived mass size distributions of super-micron particles before the volcanic episode (03:00-06:00 local summer time on 25 May), during the episode (06:30-17:30), and after it (18:0021:00). A density of $2.6 \mathrm{~g} \mathrm{~cm}^{-3}$ has been assumed in converting the APS data.

super-micron particulate matter. Our earlier measurements suggest that besides sea salt, the super-micron size range is likely to include road dust, other mineral particles, and primary biogenic particles in the Helsinki area (e.g. Pakkanen et al., 2001; Viidanoja et al., 2002). As will be shown in

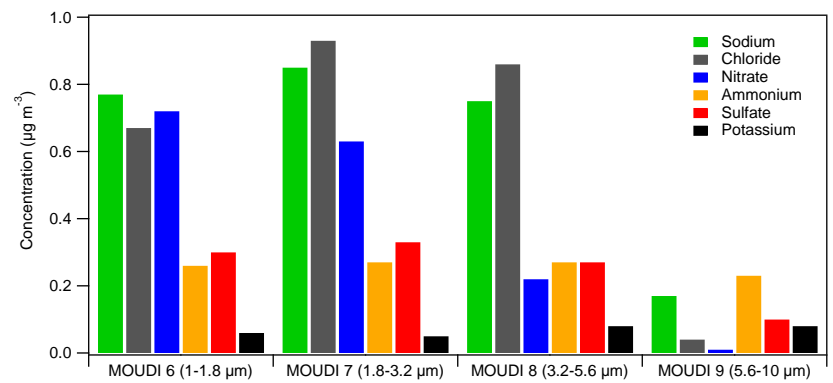

Fig. 6. Concentrations of sodium, chloride, nitrate, ammonium, sulfate and potassium in the four size ranges obtained by the IC measurements from the MOUDI sample that was collected between 15:15 and 17:00 during the episode on 25 May.

Sect. 3.3, the great majority of super-micron particulate matter during the episode on 25 May was volcanic ash rather than other primary particles more typical to our measurement site.

Additional information on the origin and atmospheric processing of super-micron particles can be obtained by looking at the relative abundances of the measured inorganic ions in different size fractions. We calculated that about half of the chloride originally present in sea-salt particles had been replaced with other acidic substances, mostly nitrate and sulfate, before entering our measurement site. Excluding the largest size range, the extent of chloride depletion 


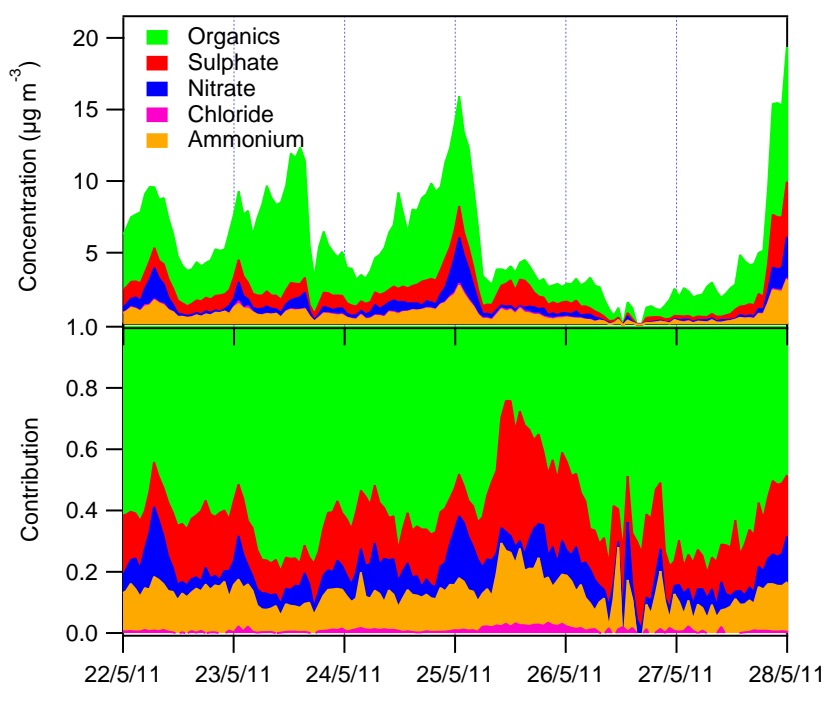

Fig. 7. Mass concentrations (top panel) and relative abundances (bottom panel) of particulate organic matter, sulfate, nitrate, ammonium and sodium measured by the ACSM in the $\mathrm{PM}_{1}$ aerosol particles between 22 and 28 May 2011.

decreased with increasing particle size similar to what has been observed in a large number of field experiments around the world (see, e.g. Kerminen et al., 1998, and references therein). Consistent with the surface reaction of gaseous nitric acid with sea-salt or other super-micron particles, the mass fraction of nitrate of the all measured inorganic ions decreased strongly with increasing particle size, being equal to $26,20,9$ and $2 \%$ in the four size ranges. Non-sea-salt sulfate was relatively evenly distributed between particles of different size. The size range 5.6-10 $\mu \mathrm{m}$ contained very little chloride but quite large mass fractions of ammonium, potassium and non-sea-salt sulfate. This feature suggests that particles other than sea salt had been present, and that these particles had interacted with sea-salt during the atmospheric transportation.

Next, let us have a look at the chemistry of sub-micron particles. The top panel of Fig. 7 shows the concentrations of compounds measured by the ACSM between 22 and 28 May 2011. We may see that nitrate and particulate organic matter $(\mathrm{POM})$ concentrations in $\mathrm{PM}_{1}$ were lower during the volcanic episode than during most other times of the considered time period. Contrary to this, sulfate concentrations were at their highest during the episode. The enrichment of sulfate in $\mathrm{PM}_{1}$ during the episode is evident when looking at the relative abundance of the compounds measured by the ACSM (bottom panel of Fig. 7).

The annual-average concentrations of sulfate and POM (assumed to be 1.6 times the organic carbon concentration) in $\mathrm{PM}_{1}$ have been observed to be about 1.5 and $2.4 \mu \mathrm{g} \mathrm{m}^{-3}$, respectively, at our measurement site (Saarikoski et al., 2008). Based on this and the findings above, it might be tempting to conclude that a big fraction of the sulfate in $\mathrm{PM}_{1}$ and nonsea-salt sulfate in super-micron particles was of volcanic origin during the 25 May episode. Before drawing this conclusion, however, we need to keep in mind that also sources other than volcanoes are able to result in high sulfate-toPOM concentration ratios. Timonen et al. (2008) found that sulfate-to-POM concentration ratios comparable to that during the volcanic episode on 25 May are frequently observed in air masses coming from continental Europe or Russia to our measurement site. In air masses originating from marine areas, such as the air measured practically the whole time period between 22 and 28 May, sulfate concentrations are typically lower than POM concentrations (Timonen et al., 2008).

Similar to the $\mathrm{PM}_{1}$ mass concentrations, the scattering and absorption coefficients of sub-micron particles did not show any notable increase during the episode (data not shown). The removal of the $\mathrm{PM}_{1}$ inlet from the nephelometer for three hours during the episode resulted in the increase of the aerosol scattering coefficients by factors of 3-4, presumably due to high concentrations of super-micron particles at that time. Even after removing the inlet, the aerosol scattering coefficients were lower than during the periods of the highest $\mathrm{PM}_{1}$ concentrations encountered between 22 and 28 May. Measured visibility anti-correlated with the aerosol scattering coefficient and showed a minor decline during the volcanic episode. We may conclude that a volcanic air pollution episode of the magnitude observed here causes an optical signal that may be difficult to be distinguished from the "normal" variability in aerosol optical properties caused by changes in concentrations other pollutants present in continental boundary layers.

\subsection{Individual particle analysis}

Both the physical and chemical aerosol properties discussed in the previous section are fully consistent with the entrance of volcanic material at our measurement site on 25 May. However, based solely on the measurements considered so far, we cannot entirely exclude the possibility that this episode was mainly or partly caused by a suitable combination of some other particle types, such as biological particles, soil dust or road dust mixed with anthropogenic pollution. By relying on individual particle analysis, we will next show that a very big fraction of super-micron particles observed during the event were indeed volcanic ash, and that some volcanic material was also present in the sub-micron size range.

A total of 193 particles collected on TEM grids during the episode were exposed to the TEM/EDX individual particle analysis. In addition to the elemental spectra, we recorded the size, morphological information and susceptibility to damage by an electron beam for all these particles. The particles were classified into different particle clusters (= groups) based on their major elements ( $\mathrm{Na}, \mathrm{Mg}, \mathrm{Al}, \mathrm{Si}, \mathrm{P}, \mathrm{S}, \mathrm{Cl}, \mathrm{K}$, $\mathrm{Ca}$, Ti and $\mathrm{Fe}$ ) using hierarchical cluster analysis (Ward's 


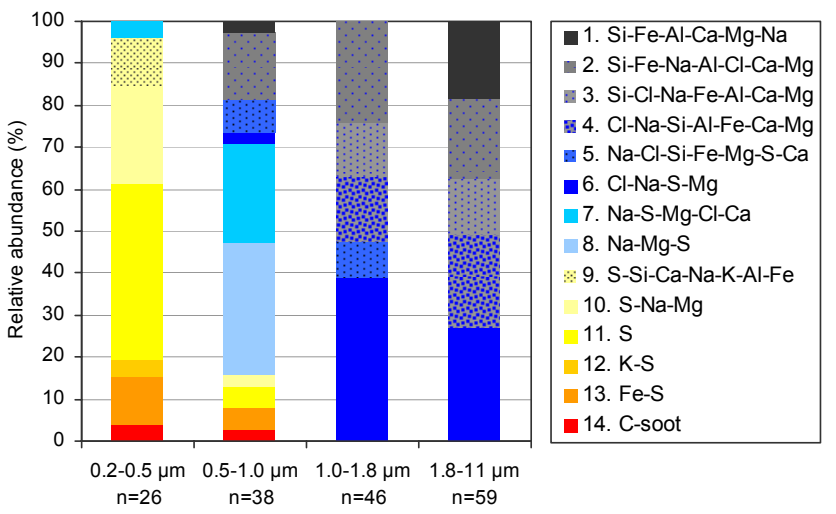

Fig. 8. Relative abundances (\%) of 14 particle groups in the four size fractions obtained by the TEM/EDX individual particle analysis from the Battelle sample that was collected between 11:37 and 15:05 local summer time during the episode on 25 May.

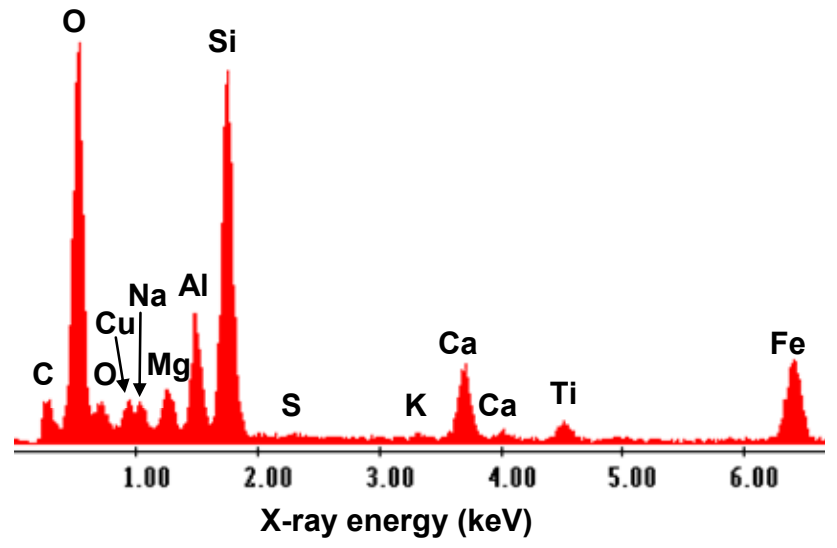

Fig. 9. An EDX spectrum of a typical particle from the group 1, i.e. pure volcanic ash particle. $\mathrm{C}$ and $\mathrm{Cu}$ peaks originate from TEM grid substrate.

method, Squared Euclidean distances; IBM SPSS Statistics 19 program). We tested for a different number of clusters and ended up to 13 groups. Carbon results were not used in cluster analysis due to its presence in the carbon-Formvar coating of TEM-grids. However, C-rich soot particles were indentified before cluster analysis based on their morphology and high $\mathrm{C}$ intensity compared with X-ray spectra analyzed from blank carbon-Formvar coating. Thus, the soot particles formed the 14th particle group. Other C-rich primary particles, such as tar balls from biomass burning or various biological particles (Niemi et al., 2006), were not observed in the $0.2-11 \mu \mathrm{m}$ size range.

The 14 particle groups and their major elements (excluding $\mathrm{O}, \mathrm{N}, \mathrm{C}$ and $\mathrm{H}$ ) in the four size fractions are shown in Fig. 8. Particles in group 1 were mainly in the $1.8-11 \mu \mathrm{m}$ size fraction and contained abundant $\mathrm{Si}$ (mean $42 \%$ of Xray counts), $\mathrm{Fe}(14 \%), \mathrm{Al}(13 \%), \mathrm{Ca}(12 \%)$ and $\mathrm{Mg}(7 \%)$ as well as some $\mathrm{Na}(4 \%)$ and $\mathrm{Ti}(3 \%)$ (Fig. 9). Further- more, very minor amounts of $\mathrm{K}, \mathrm{P}, \mathrm{Cl}$ and $\mathrm{S}$ were observed in some particles. We compared the elemental ratios of group 1 with the corresponding values reported for Grimsvötn volcanic ash fallout collected from Iceland during the eruption on 22 May 2011 (Oskarsson and Sverrisdóttir, 2011). These two sets of the elemental ratios were very close to each other, which confirm that particles in group 1 represent "pure" volcanic ash from the Grimsvötn eruption in the sense that the ash particles had not been interacted with other type of particles before entering our measurement site. The elemental composition of ash particles was very homogenous, as typical for volcanic ash from Grimsvötn tholeiite-basalt rock (Oskarsson and Sverrisdóttir, 2011).

In general, the 14 particle groups chosen in this paper represent particles ranging from "pure" ash (group 1) to ash mixed with sea salt (groups 2-5), sea salt particles with variable degrees of $\mathrm{Cl}$ substitution by sulphate or nitrate due to interaction with trace gases (groups 6-8), particles containing mostly secondary material, such as ammonium, sulphate, nitrate and organic compounds (groups 9-12), and combustion-derived primary particles, such ash soot and Ferich particles with secondary material (groups 13-14). Examples of different particle types are illustrated in Fig. 10. Volcanic ash particles were totally beam-resistant and their shapes were very variable from angular oval particles to angular flakes or rods, containing sometimes very sharp edges. The submicron secondary particles were easily damaged under intentional, strong electron beam, as typical for these particle types (Niemi et al., 2006).

Figure 8 summarizes the relative abundances of the different particles types in the size ranges $0.2-0.5 \mu \mathrm{m}, 0.5-1.0 \mu \mathrm{m}$, $1.0-1.8 \mu \mathrm{m}$ and $1.8-11 \mu \mathrm{m}$. We may see that the largest size range contained almost exclusively "pure" volcanic ash particles $(\sim 20 \%)$ and relatively fresh sea-salt particles $(\sim 30 \%)$, or mixtures of these two particle types $(\sim 50 \%)$. The size range of $1.0-1.8 \mu \mathrm{m}$ resembled the largest size range, but with the difference that there were fewer ash particles and almost no particles that could be termed as "pure" ash. The size range of $0.5-1.0 \mu \mathrm{m}$ was dominated by reacted sea-salt particles followed by ash particles. In this size range, also small numbers of primary combustion and secondary particles appeared. The smallest size range was dominated by secondary particles and primary combustion particles, and it had a small fraction of reacted sea salt particles. After more accurate inspection of the TEM grids and subsequent selective analysis, we were able to found ash particles also from this smallest size range. Their abundance in relation to other particles types was, however, almost negligible. Figure 11 demonstrates the smallest volcanic ash particle from the 0.2 $0.5 \mu \mathrm{m}$ sample and the largest ash particle from the $>11 \mu \mathrm{m}$ sample that contained only two volcanic ash particles and one primary biological particle.

The presence of substantial amounts of mixed ash-sea salt particles indicates that the volcanic ash had entrained into the boundary layer air well before entering our measurement 
PM 1.8-11 $\boldsymbol{\mu m}$ : Pure volcanic ash (1), mixed volcanic ash and sea salt (2-4), sea salt (6).

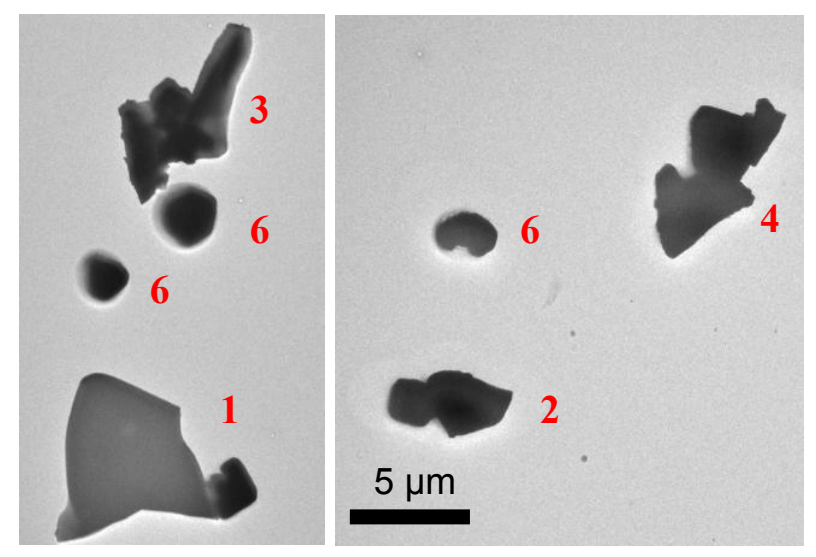

PM 1.0-1.8 $\boldsymbol{\mu m}$ : Mixed volcanic ash and sea salt (2-3), sea salt (6).

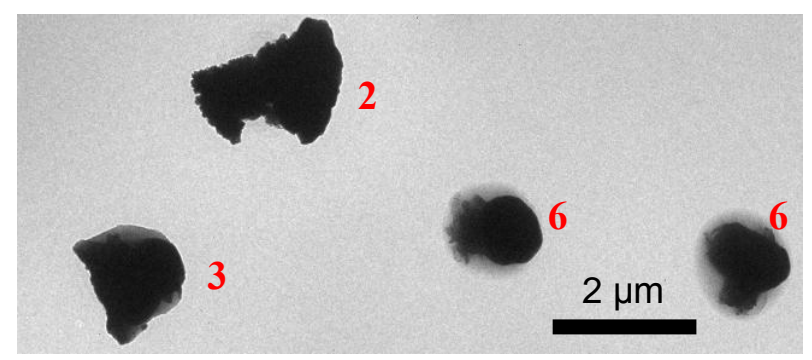

PM 0.5-1.0 $\mu \mathrm{m}$ : Sea salt with high level of $\mathrm{Cl}$ depletion $(7-8)$.

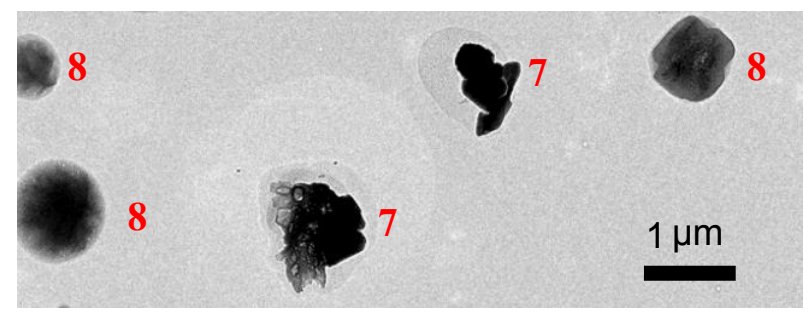

PM 0.2-0.5 $\boldsymbol{\mu m}$ : Secondary particles $(10,11)$, Fe-rich with secondary material (13), soot particle (14).

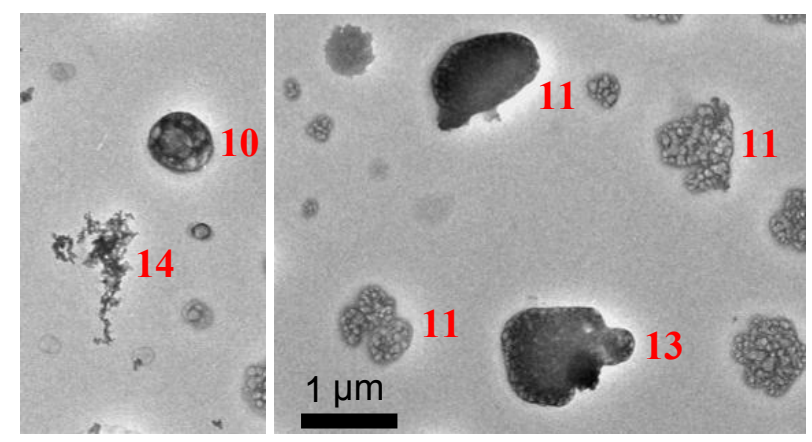

Fig. 10. TEM images of typical particle types in four size fractions from the Battelle sample that was collected between 11:37 and 15:05 local summer time during the episode on 25 May. The numbering of particle types is the same as in Fig. 8 .
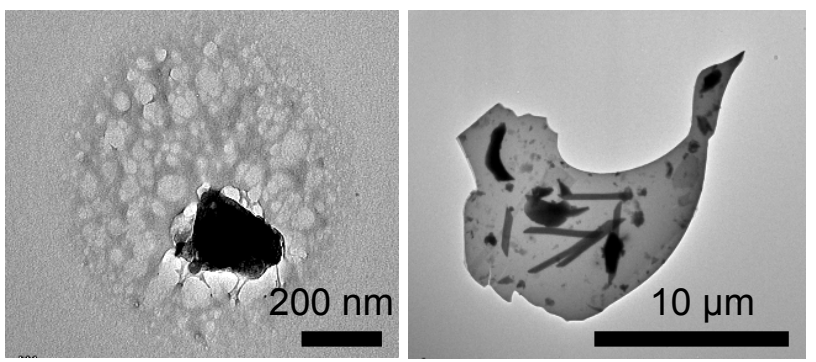

Fig. 11. TEM images of volcanic ash mixed with secondary material in the $0.2-0.5 \mu \mathrm{m}$ sample (left image) and volcanic ash in the $>11 \mu \mathrm{m}$ sample (right image) collected between 11:37 and 15:05 local summer time during the episode on 25 May.

site. The entrainment could not be due to gravitational settling alone, since settling velocities of sub-micron ash particles are expected to be very low. One could note that submicron ash particles in surface air were also detected in association with the Eyjafjallajökull eruption in April, 2010 (Lettino et al., 2011).

Our individual particle analysis unambiguously demonstrates that volcanic ash particles were present at sizes from less than $0.5 \mu \mathrm{m}$ up to sizes $>10 \mu \mathrm{m}$ at our measurement site during the May 25 episode. Together with sea-salt, ash appeared to account for the great majority of super-micron particles in terms of particle number. Estimating the exact contribution of ash to super-micron particulate mass is complicated due to their variable sizes and partial mixing with sea salt and other particle. Based on their big share in the collected sample, however, it is very likely that volcanic was the main component of super-micron particle mass during the episode, enhancing $\mathrm{PM}_{10}$ mass concentrations up to several tens of $\mu \mathrm{g} \mathrm{m}^{-3}$. Such an enhancement is comparable to observed maximum increases of $\mathrm{PM}_{10}$ mass concentrations in France and Germany after the Eyjaflallajökull eruption (Colette et al., 2011; Schäfer et al., 2011).

\section{Conclusions}

The investigation made in this paper has demonstrated the power of combining surface aerosol measurements, dispersion model simulations and satellite measurements in detecting and analyzing surface air pollution episodes caused by long-range transported material from volcanic eruptions. None of these three approaches alone would be sufficient for this purpose. Satellite measurements, while easily detecting a major volcanic plume in cloud-free air, become less accurate in following weak and diluting plumes further away from volcanoes. Furthermore, most satellites are not yet able to provide detailed information about the size and vertical location of volcanic particles. Dispersion model calculations are extremely useful in following the atmospheric transportation 
of volcanic material, but have challenges in predicting the entrainment of this material into the boundary layer air. Routine air pollution monitoring reveals the presence of significant amounts of volcanic material in the surface air but, without complementary and very detailed aerosol measurements, cannot unambiguously tell us whether elevated pollutant concentrations are due to volcanic emissions or some other sources.

Similar to the detection of volcanic material in the surface air, forecasting of air pollution episodes caused by volcanic eruptions requires the complementary use of remote sensing, dispersion model simulations, and surface air monitoring. The first two of these methods are needed to identify and foresee the situations in which volcanic material might have transported over different locations. By combining this information with data from a sufficiently large and near realtime air pollution network, people susceptible to air pollution will get some time to prepare themselves for the arrival of volcanic pollution.

Acknowledgements. This study has been funded by the Academy of Finland (projects IS4FIRES and ASTREX), by the CLEEN/MMEA program and the KASTU-2 project (decision number 40396/10) of the Finnish Funding Agency for Technology and Innovation (TEKES), and by EU FP7 MACC projects. We would also like to thank Electron Microscopy Unit of the Institute of Biotechnology, University of Helsinki, for providing laboratory facilities. The authors gratefully acknowledge the NOAA Air Resources Laboratory (ARL) for the provision of the HYSPLIT transport and dispersion model and/or READY website (http://www.arl.noaa.gov/ready.php) used in this publication.

Edited by: M. C. Facchini

\section{References}

Allen, G., Sioutas C., Koutrakis, P., Reiss, R., Lurmann, F. W., and Roberts, P. T.: Evaluation of the TEOM method for measurement of ambient particulate mass in urban areas, J. Air Waste Manage. Assoc., 14, 682-689, 1997.

Ansmann, A., Tesche, M., Gross, S., Freudenthaler, V., Seifert, P., Hiebsch, A., Schmidt, J., Wandinger, U., Mattis, I., Müller, D., and Wiegner, M.: The 16 April 2010 major volcanic ash plume over central Europe: EARLINET lidar and AERONET photometer observations at Leipzig and Munich, Germany, Geophys. Res. Lett., 37, L13810, doi:10.1029/2010GL043809, 2010.

Anttila, P. and Salmi, T.: Characterizing temporal and spatial patterns of urban $\mathrm{PM}_{10}$ using six years of Finnish monitoring data, Boreal Environ. Res., 11, 463-479, 2006.

Anttila, P. and Tuovinen, J.-P.: Trends of primary and secondary pollutant concentrations in Finland in 1994-2007, Atmos. Environ., 44, 30-41, 2010.

Colette, A., Favez, O., Meleux, F., Chiappini, L., Maeffeli, M., Morille, Y., Malherbe, L., Papin, A., Bessagnet, B., Menut, L., Leoz, E., and Rouil, L.: Assessing in near real time the impact of the April 2010 Eyjafjallajökull ash plume on air quality, Atmos. Environ., 45, 1217-1221, 2011.
Dirksen, R. J., Boersma, K. F., de Laat, J., Stammes, P., van der Werf, G. R., Val Martin, M., and Kelder, H. M.: An aerosol boomerang: Rapid around-the-world transport of smoke from the December 2006 Australian forest fires observed from space, J. Geophys. Res., 114, D21201, doi:10.1029/2009Jd012360, 2009.

Draxler, R. R. and Rolph, G. D.: HYSPLIT (Hybrid Single-Particle Lagrangian Integrated Trajectory) Model, access via NOAA ARL READY Website: http://ready.arl.noaa.gov/HYSPLIT.php, NOAA Air Resources Laboratory, Silver Spring, MD, USA, 2011.

Flentje, H., Claude, H., Elste, T., Gilge, S., Köhler, U., PlassDülmer, C., Steinbrecht, W., Thomas, W., Werner, A., and Fricke, W.: The Eyjafjallajökull eruption in April 2010 - detection of volcanic plume using in-situ measurements, ozone sondes and lidar-ceilometer profiles, Atmos. Chem. Phys., 10, 1008510092, doi:10.5194/acp-10-10085-2010, 2010.

Galperin M. V.: Approaches for improving the numerical solution of the advection equation. In: Large-Scale Computations in Air Pollution Modelling, edited by: Zlatev Z., Brandt, J., Builtjes, P. J. H., Carmichael, G., Dimov, I., Dongarra, J., Van Dop, H., Georgiev, K., Hass, H., and San José, R., Proc. NATO Advanced Research Workshop on Large Scale Computations in Air Pollution Modelling, Sofia, Bistritza, 6-10 July 1998, Kluiwer Academic Publishers, The Netherlands, 161-172, 1999.

Galperin M. V.: The Approaches to Correct Computation of Airborne Pollution Advection. In: Problems of Ecological Monitoring and Ecosystem Modelling, St. Petersburg, Gidrometeoizdat, XVII, 54-68, in Russian, 2000.

Gasteiger, J., Gros, S., Freudenthaler, V., and Wiegner, M.: Volcanic ash from Iceland over Munich: mass concentration retrieved from ground-based remote sensing measurements, Atmos. Chem. Phys., 11, 2209-2223, doi:10.5194/acp-11-22092011, 2011.

Gislason, S. R., Hassenkam, T., Nedel, S., Bovet, N., Eiriksdottir, E. S., Alfredsson, H. A., Hem, C. P., Balogh, Z. I., Dideriksen, K., Oskarsson, N., Sigfusson, B., Larsen, G., and Stipp, S. L. S.: Characterization of Eyjafjallajökull volcanic ash particles and a protocol for rapid risk assessment, P. Natl. Acad. Sci., 108, 73077312, doi:10.1073/pnas.1015053108, 2011.

Graf, H.-F., Li, Q., and Giorgetta, M. A.: Volcanic effects on climate: revisiting the mechanisms, Atmos. Chem. Phys., 7, 45034511, doi:10.5194/acp-7-4503-2007, 2007.

Guffani, M., Mayberry, G. C., Casadevall, T. J., and Wunderman, R.: Volcanic hazards to airports, Nat. Hazards, 51, 287-302, doi:10.10007/s11069-008-9254-2, 2009.

Horn, H.-G., Bonka, H., and Maqua, M.: Measured particle bound activity size-distribution, deposition velocity, and activity concentration in rainwater after the Chernobyl accident, J. Aerosol Sci., 18, 681-684, 1987.

Järvi, L., Hannuniemi, H., Hussein, T., Junninen, H., Aalto, P. P., Hillamo, R., Mäkelä, T., Keronen, P., Siivola, E., Vesala, T., and Kulmala, M.: The urban measurement station SMEAR III: Continuous monitoring of air pollution and surface-atmosphere interactions in Helsinki, Finland, Boreal Env. Res., 14, Suppl. A, 2009.

Jylhä, K.: Empirical scavenging coefficients of radioactive substances released from Chernobyl, Atmos. Environ., 25A, 263270, 1991.

Kerminen, V.-M., Teinilä, K., Hillamo, R. E., and Pakkanen, T.: 
Substitution of chloride in sea-salt particles by inorganic and organic anions, J. Aerosol Sci., 29, 929-942, 1998.

Kerminen, V.-M., Ojanen, C., Pakkanen, T., Hillamo, R., Aurela, M., and Meriläinen, J.: Low-molecular-weight dicarboxylic acids in an urban and rural atmosphere, J. Aerosol Sci., 31, 349$362,2000$.

Krotkov, N. A., Carn, S. A., Krueger, A. J., Bhartia, P. K., and Yang, K.: Band residul difference algorithm for retrieval of $\mathrm{SO}_{2}$ from the Aura Ozone Monitoring Instrument (OMI), IEE Trans. Geosci. Remote Sens., 44, 1259-1266, 2006.

Kupiainen, K. J. and Pirjola, L.: Vehicle non-exhaust emissions from the tyre-road interface - effect of stud properties, traction sanding and resuspension, Atmos. Environ., 45, 4141-4146, 2011.

Levelt, P. F., Hinsenrath, E., Leppelmeier, G. W., van den Oord, G. H. J., Bhartia, P. K., Tamminen, J., de Haan, J. F., and Veefkind, J. P.: Science objectives of the Ozone Monitoring Instrument, IEE Trans. Geosci. Remote Sens., 44, 1199-1208, 2006.

Lettino, A., Caggiano, R., Fiore, S., Macchiato, M., Sabia, S., and Trippettta, S.: Eyjafjallajökull volcanic ash in southern Italy, Atmos. Environ., in press, 2011.

Liu, B. Y. and Pui, D. Y.: Aerosol sampling inlets and inhalable particles, Atmos. Environ., 15, 585-600, 1981.

Liu, P. S. K., Deng, R., Smith, K. A., Williams, L. R. , Jayne, J. T., Canagaratna, M. R., Moore, K., Onasch, T. B., Worsnop, D. R. and Deshler, T.: Transmission Efficiency of an Aerodynamic focusing Lens System: Comparison of Model Calculations and Laboratory Measurements for the Aerodyne Aerosol Mass Spectrometer, Aerosol Sci. Technol., 41, 721-733, 2007.

Marple, V. A., Rubow, K. L., and Behm, S. M.: A Microorifice Uniform Deposit Impactor (MOUDI): Description, calibration and use, Aerosol Sci. Technol., 14, 434-446, 1991.

Mastin, L.G., Guffanti, M., Servranchx, R., Webley, P., Barsotti, S., Dean, K., Durant, A., Ewert, J. W., Neri, A., Rose, W. I., Schneider, D., Siebert, L., Stunder, B., Swanson, G., Tupper, A., Volentik, A., and Waythomas, C. F.: A multidisciplinary effort to assign realistic source parameters to models of volcanic ash-cloud transport and dispersion during eruptions, J. Volcanol. Geotherm. Res., 186, 10-21, 2009.

Mitchell, R. I. and Pilcher, J. M.: Improved cascade impactor for measuring aerosol particle sizes, Ind. Eng. Chem., 51, 1039$1042,1959$.

Ng, N. L., Herndon, S. C., Trimborn, A., Canagaratna, M. R., Croteau, P. L., Onasch, T. B., Sueper, D., Worsnop, D. R., Zhang, Q., Sun, Y. L. and Jayne, J. T.: An Aerosol Chemical Speciation Monitor (ACSM) for Routine Monitoring of the Composition and Mass Concentrations of Ambient Aerosol, Aerosol Sci. Technol., 45, 770-784, 2011.

Niemi, J. V., Saarikoski, S., Tervahattu, H., Mäkelä, T., Hillamo, R., Vehkamäki, H., Sogacheva, L., and Kulmala, M.: Changes in background aerosol composition in Finland during polluted and clean periods studied by TEM/EDX individual particle analysis, Atmos. Chem. Phys., 6, 5049-5066, doi:10.5194/acp-6-50492006, 2006.

Niemi, J. V., Saarikoski, S., Aurela, M., Tervahattu, H., Hillamo, R., Westphal, D. L., Aarnio, P., Koskentalo, T., Makkonen, U., Vehkamäki, H., and Kulmala, M.: Long-range transport episodes of fine particles in sourthern Finland during 1999-2007, Atmos. Environ., 43, 1255-1264, 2009.
Oskarsson, N. and Sverrisdóttir, G.: Chemical composition and texture of ash from the Grimsvotn 2011-eruption. Institute of Earth Sciences, University of Iceland, 2011, available online at: http://earthice.hi.is/page/ies_GV2011_chemical, lass access: 1 December 2011.

Pakkanen, T. A., Kerminen, V.-M., Korhonen, C. H., Hillamo, R. E., Aarnio, P., Koskentalo, T., and Maenhaut, W.: Use of atmospheric elemental size distributions in estimating aerosol sources in the Helsinki area, Atmos. Environ., 35, 5537-5551, 2001.

Petäjä, T., Laakso, L., Grönholm, T., Launiainen, S., EvelePeltoniemi, I., Virkkula, A., Leskinen, A., Backman, J., Manninen, H. E., Sipilä, M., Haapanana, S., Hämeri, K., Vanhala, E., Tuomi, T., Paatero, J., Aurela, M., Hakola, H., Makkonen, U., Hellen, H., Hillamo, R., Vira, J., Prank, M., Sofiev, M., SiitariKauppi, M., Laaksonen, A., Lehtinen, K. E. J., Kulmala, M., Viisanen, Y., and Kerminen, V.-M.: In-situ observations of Eyjafjallajökull ash particles by hot-air balloon, Atmos. Environ., in press, 2011.

Prata, A. J.: Satellite detection of hazardous volcanic clouds and the risk to global air traffic, Nat. Hazards, 51, 303-324, doi:10.1007/s11069-008-9273-z, 2009.

Prata, A. J. and Kerkman, J.: Simultaneous retrieval of volcanic ash and $\mathrm{SO}_{2}$ using MSG-SEVIRI measurements, Geophys. Res. Lett., 34, L05813, doi:10.1029/2006GL028691, 2007.

Revuelta, M. A., Sastre, M., Fernandez, A. J., Martin, L., Garcia, R., Gomez-Moreno, F. J., Artininano, B., Pujadas, M., and Molero, F., Characterizing of the Eyjafjallajökull volcanic plume over the Iberian Peninsula by lidar remote sensing and ground-level data collection, Atmos. Environ., in press, 2011.

Robock, A.: Volcanic eruptions and climate, Rev. Geophys., 38, 191-219, 2000.

Rolph, G. D.: Real-time Environmental Applications and Display sYstem (READY) Website: http://ready.arl.noaa.gov, NOAA Resources Laboratory, Silver Spring, MD, USA, 2011.

Rossini, P., Molinaroli, E., De Falco, G., Fiesoletti, F., Papa, G., Pari, E., Renzulli, A., Tentoni, P., Testoni, A., Valentini, L., and Matteucci, G.: April-May 2010 Eyjaflallajökull volcanic fallout over Rimini, Italy, Atmos. Environ., in press, 2011.

Saarikoski, S., Timonen, H., Saarnio, K., Aurela, M., Järvi, L., Keronen, P., Kerminen, V.-M., and Hillamo, R.: Sources of organic carbon in fine particulate matter in northern European urban air, Atmos. Chem. Phys., 8, 6281-6295, doi:10.5194/acp-86281-2008, 2008.

Schneider, D. J., Rose, W. I, Coke, L. R., and Bluth, G. J. S.: Early evolution of a stratospheric volcanic eruption cloud as observed with TOMS and AVHRR, J. Geophys. Res., 104, 4037-4050, 1999.

Schneider, D. P., Ammann, C. M., Otto-Bliesner, B. L., and Kaufman, D. S.: Climate response to large, highlatitude and low-altitude volcanic eruptions in the Community Climate System Model, J. Geophys. Res. 114, D15101, doi:10.1029/2008JD011222, 2009.

Schumann, U., Weinzierl, B., Reitebuch, O., Schlager, H., Minikin, A., Forster, C., Baumann, R., Sailer, T., Graf, K., Mannstein, H., Voigt, C., Rahm, S., Simmet, R., Scheibe, M., Lichtenstern, M., Stock, P., Rüba, H., Schäuble, D., Tafferner, A., Rautenhaus, M., Gerz, T., Ziereis, H., Krautstrunk, M., Mallaun, C., Gayet, J.-F., Lieke, K., Kandler, K., Ebert, M., Weinbruch, S., Stohl, A., Gasteiger, J., Groß, S., Freudenthaler, V., Wiegner, M., Ans- 
mann, A., Tesche, M., Olafsson, H., and Sturm, K.: Airborne observations of the Eyjafjalla volcano ash cloud over Europe during air space closure in April and May 2010, Atmos. Chem. Phys., 11, 2245-2279, doi:10.5194/acp-11-2245-2011, 2011.

Sillanpää, M., Saarikoski, S., Hillamo, R., Pennanen, A., Makkonen, U., Spolnik, Z., Van Grieken, R., Koskentalo, T., and Salonen, R. O.: Chemical composition, mass size distribution and source analysis of long-range transported wildfire smokes in Helsinki, Sci. Total Environ., 350, 119-135, 2005.

Slinn, S. and Slinn, W.: Predictions for particle deposition on natural waters, Atmos. Environ., 14, 1013-1016, 1980.

Smith, F. B. and Clark, M. J.: The transport and deposition of radioactive debris from the Chernobyl nuclear power plant accident with special emphasis on consequences to the United Kingdom, Meterorological Office Scientific Paper, N42, HMSO, London, UK, 1989.

Schäfer, K., Thomas, W., Peters, A., Ries, L., Obleitner, F., Schnelle-Kreis, J., Birmili, W., Diemer, J., Fricke, W., Junkermann, W., Pitz, M., Emeis, S., Forkel, R., Suppan, P., Flentje, H., Gilge, S., Wichmann, H. E., Meinhardt, F., Zimmermann, R., Weinhold, K., Soentgen, J., Münkel, C., Freuer, C., and Cyrys, J.: Influences of the 2010 Eyjafjallajökull volcanic plume on air quality in the northern Alpine region, Atmos. Chem. Phys., 11, 8555-8575, doi:10.5194/acp-11-8555-2011, 2011.

Sofiev, M.: Extended resistance analogy for construction of the vertical diffusion scheme for dispersion models, J. Geophys. Res., 107, 4152, doi:10.1029/2001JD001233, 2002.

Sofiev, M., Galperin, M., and Genikhovich, E.: Construction and evaluation of Eulerian dynamic core for the air quality and emergency modelling system SILAM, NATO Science for piece and security Series C: Environmental Security. Air pollution modelling and its application, XIX, edited by: Borrego, C. and Miranda, A. I., Springer, Dordrecht, The Netherlands, 699-701, 2008.

Sofiev, M., Siljamo, P., Valkama, I., Ilvonen, M., and Kukkonen, J.: A dispersion modelling system SILAM and its evaluation against ETEX data, Atmos. Environ., 40, 674-685, 2006.
Sofiev, M., Genikhovich, E., Keronen, P., and Vesala, T.: Diagnosing the surface layer parameters for dispersion models within the meteorological-to-dispersion modelling interface, J. Appl. Meteorol. Climatol., 49, 221-233, doi:10.1175/2009JAMC2210.1, 2010.

Tervahattu, H., Hongisto, M., Aarnio, P., Kupiainen, K., and Sillanpää, M.: Coposition and origins of aerosol during a high $\mathrm{PM}_{10}$ episode in Finland, Boreal Environ. Res., 9, 335-345, 2004.

Thordarson, T. and Self, S.: Atmospheric and environmental effects of the 1783-1784 Laki eruption: A review and reassessment, J. Geophys. Res., 108, 4011, doi:10.1029/2001JD002042, 2003.

Timonen, H., Saarikoski, S., Tolonen-Kivimäki, O., Aurela, M., Saarnio, K., Petäjä, T., Kulmala, M., Pakkanen, T., and Hillamo, R.: Size distributions, sources and source areas of water-soluble organic carbon in urban background air, Atmos. Chem. Phys., 8, 5635-5647, doi:10.5194/acp-8-5635-2008, 2008.

Torres, O., Bhartia, P. K., Herman, J. R., Ahmad, Z., and Gleason, $\mathrm{J}$.: Derivation of aerosol properties from satellite measurements of backscattered ultraviolet radiation: Theoretical basis, J. Geophys. Res., 103, 17099-17110, 1998.

Torres, O., Tanskanen, A., Veihelmann, B., Ahn, C., Braak, R., Bhartia, P. K., Veefkind, P., and Levelt, P.: Aerosol and surface UV products from Ozone Monitoring Instrument observations: An overview, J. Geophys. Res., 112, D24S47, doi:10.1029/2007JD008809, 2007.

Vallius, M., Lanki, T., Tiittanen, P., Koistinen, K., Ruuskanen, J., and Pekkanen, J.: Source apportionment of urban ambient $\mathrm{PM}_{2.5}$ in two successive measurement campaign in Helsinki, Finland, Atmos. Environ., 37, 615-623, 2003.

Viidanoja, J., Sillanpää, M., Laakia, J., Kerminen, V.-M., Hillamo, R., Aarnio, P., and Koskentalo, T.: Organic and black carbon in $\mathrm{PM}_{2.5}$ and $\mathrm{PM}_{10}$ : 1 year of data from an urban site in Helsinki, Finland, Atmos. Environ., 36, 3183-3193, 2002. 